stone marks the grave of Lizzie Rutherford Ellis, crediting her with the suggestions for originating Memorial Day.

In Waterloo, N. Y., Henry C. Welles and Gen. John B. Murray are given credit as the originators of the day. Their first observance was May 5, 1866. Their claim is qualified as the "first formal village-wide observance of the day." By a Joint Resolution of Congress, Waterloo has been recognized the "The Birthplace of Memorial Day."

\title{
CIVIL WAR EXPERIENCES OF JOHN MCALLISTER
}

The following article was taken from the CEDAR RAPIDS Republican, April 10, 1927. The article was entitled "John McAllister, Civil War Veteran, Was Confined in Libby Prison for Three Months; Wounded in Battle" and was written by Russell C. Landstrom.

"I have heard people say that they would rather starve than eat a certain thing, but that isn't true; a hungry man will eat anything. When we were in Libby prison we were glad to eat absolutely anything - even bugs and maggots. During those months I realized the truth of what I had often read, but disbelieved-that men could eat their own flesh."

Thus speaks John McAllister, 1526 Second avenue, 86year-old Civil War veteran and former member of the Iowa state legislature.

That was in 1863.

John McAllister, with a wounded left hand, had been taken prisoner in Tennessee by Confederates and shipped with other Union soldiers to the infamous Libby prison at Richmond, Va.

The trainload of prisoners had been moving about the country for days-from Tennessee to Georgia-from Georgia 
to Montgomery, Ala.-back to Tennessee-to Ohio, and then to Libby prison.

Only once had the prisoners been released from the rude box cars in the 15 days and 15 nights of the trip. Many were half starved and a number of them died en route. In Chattanooga McAllister and some of his comrades procured some raw corn meal to which they added water, stirring the two into a sort of porridge, unpalatable but sufficiently filling to destroy the feeling of weak emptiness.

The soldiers had been packed in the cars until none could sit or lie down with even the slightest degree of comfort. The smell of the cars was frightful, for wounds were not dressed, bodies were unclean, and clothing was in a state of utter disorder. In order that they might get a breath of fresh, clean air some of the men knocked out boards from the sides of the cars, and thrust their heads out through the openings, sniffing like animals.

The train arrived in Richmond in the night, and the prisoners were hustled out of the cars. What little money the men possessed was taken from them in exchange for Confederate script. Overcoats were snatched from the backs of the soldiers, as they were pushed and shoved into Libby prison, an old tobacco warehouse on the banks of the James river.

They were forced to sleep on the bare floor without covering of any kind. Between 200 and 300 men crouched in the corners, or huddled around a small sheet iron stove in the room to which John McAllister was assigned. The room was further populated, but by noxious vermin that kept the wretched prisoners in a continual state of misery and torment. The room was cold, and that moved the vermin to increased activity on the persons of the men.

The prison rations were com bread and water-nothing warm and stimulating such as soups and coffee.

The prisoners were not permitted at any time to approach and peer out of the dingy windows of the second story on which McAllister was quartered. That was the dead-line. They were forced to keep their backs to the wall, and guards were there to see that the restriction was 
obeyed-guards on the first floor, and guards patroling their posts just below the windows along the James river. And occasionally a bullet came biting up through the board floor, accidentally the guards said mockingly, but the emaciated Union soldiers knew better than that.

Medical and surgical aid was denied the men, and wounds gangrened rapidly. McAllister's splintered hand swelled to twice its normal size and became sickeningly black. His best friend, John W. Williams, whom he had carried off a battlefield in Tennessee, with leg dangling from the trunk of his body, died as a result of neglect.

For three months John McAllister was confined in this terrible prison, and then on April 14, 1863, he was paroled and exchanged. $\mathrm{He}$ went to City Point, Va., and there boarded a boat which took him to Annapolis, Md. With his wounded hand healing, he went to Murfreesboro where he rejoined his regiment.

\section{Private in Co. 1, 69th Volunteer Infantry}

John McAllister entered the service March 19, 1862, at Columbus, Ohio, as a private in Company I, 69th Volunteer Infantry. He was shortly promoted to the rank of corporal, and then to that of a sergeant. He was discharged March 20, 1864, at Columbus, and re-enlisted as a veteran for the duration of the war. He was finally discharged July 17, 1865, at Louisville, $\mathrm{Ky}$.

His first taste of battle occurred at Gallatin, Tenn., and later at Stone River, Tullahoma, Chickamauga, Mission Ridge, Resaca, Ga., and Bentonville, N. C. He also accompanied Sherman on the historic march to the sea.

Vivid, indeed, are his memories of Stone River, the battle in which he was first wounded. This battle began Dec. 31,1862 , and lasted for three days. It resulted in a victory for the Union forces, but casualties were heavy, being about 18,000 on each side.

McAllister was wounded on the first day of the battle, receiving a musket ball in his left hand. Near him was his old boyhood chum, John Williams, who had received a wound which nearly severed a leg from his body. McAllister hurried to his comrade's side, and lifting him in his 
arms bore him from the field. Near an indenture in the ground was a green flag which McAllister believed to be that of a friendly hospital. But as he started for the spot he heard the sharp rebel yell and simultaneously witnessed the charge of southern troops. On they came, thousands of gray figures attaching his comrades in the army of the Cumberland. The main body of the Confederates passed over him, but finally a squad captured him and Williams, and escorted them to the rear. Soon they were en route to Libby prison.

\section{The Battle at Resaca}

At 10 o'clock on the morning of May 14, 1864, the Union forces under General Thomas made their famous attack at Resaca, Ga., in one of the most important battles of the Civil war. Behind the lines of advancing infantry light artillery and howitzers boomed steadily. Cavalry regiments occupied flank positions, and thus a long line of blue swept on to the attack.

In his company which was charging with the other outfits was John McAllister. He was on the banks of a creek when he felt a sharp, searing pain in his neck. A bullet had entered the larynx and emerged on the right side of his neck. Bones were shattered and the pain was almost unbearable.

He was quickly removed from the field and put aboard a hospital train bound for Nashville, Tenn. While en route to that city the train was fired upon by bushwhackers, and in this skirmish McAllister narrowly escaped being killed.

The pain in the wounded man's throat became more intense; the flesh on his neck was swollen and he found it impossible to move his head in any direction. He could barely whisper. And to this day he has never fully recovered his speech, but talks in a rather hoarse whisper.

From the hospital in Nashville he was conveyed to Louisville, and again moved, this time to an infirmary in Ohio, where for months he endured agony. Finally on Nov. 1 he was discharged from the hospital, and was advised by army officials to go into the veterans' reserve, which was 
doing guard duty. But John McAllister wanted to go back to his regiment, and his desire was honored.

After he had joined his old comrades for the second time McAllister was made an ordnance sergeant. That was the unforgettable year in which McAllister, in Atlanta, voted for Abraham Lincoln for president of the United States.

But an ordnance sergeant's life is not one of ease and safety, and not long after he had returned to his regiment McAllister again fortunately escaped being killed. An orderly sergeant and he were sitting in front of a pup tent at Savannah, Ga., one day when a shell from a siege gun struck a nearby pine tree and exploded with a deafening detonation and a sheet of flame. A piece of this shell, which was later found to weight eight pounds, landed at McAllister's feet and buried itself in the ground.

\section{The March to Atlanta}

One day in the last week of October, 1864, regimental buglers blew assembly, and the various outfits rolled their packs and slung their rifles in preparation for a forced march. The rank and file had no idea of the destination of the march but they strongly suspected that it was to be a long hike and an important one. The general in command of the corps was William Tecumseh Sherman.

The columns were formed in Rome, Ga., and marched down to Atlanta. On the sixteenth and seventeenth of November they burned that city in obedience to orders, and then started on their march to the sea.

Occasionally the rear guard of the line was attacked by Confederate cavalry, but these skirmishes were sporadic. On and on the blue uniformed soldiers marched, through cotton fields, past old plantations stripped of their former opulence, through quaint villages, and through Milledgeville, the old capital of Georgia.

In Milledgeville white-eyed Negros lined both sides of the street through which the Union soldiers marched.

"Here comes Marse Lincoln's soldiers - we doan't need to work anymore," they shouted as they fell in line behind Sherman's men. In time, however, they became such a bother and such a menace to orderly formation that when the troops 
reached Waynesboro they pulled. up the pontoon bridge over which they had crossed, and left the liberated slaves on the other side.

"Yes," declared McAllister in his whisper, "I knew Sherman, knew him well. He was just as common as an old shoe. He was a Lincoln type of man, in the military, of course. We all called him 'Uncle Bill.' He would do anything for a man, regardless of his rank. Many were the times when he accommodated privates whom he did not know, and whom in all probability he would never meet again."

Savannah was the end of the march to the sea, which place was reached in December. Toward the north the troops then started, until they reached Averysboro, N. C., and on March 19 they fought the battle of Bentonville, in which the division was badly cut up. McAllister served as an ordnance sergeant in this battle, going about the field carrying 1,000 rounds of ammunition on his back each trip.

That was the last battle in which his company fought. The army in this vicinity was reorganized and started north for Smithville, N. C., where in April they learned with joy that Lee had surrendered. In a few days their joy was transformed to sorrow, for runners carried the distressing news that President Lincoln had been shot in Ford's theater.

"We could hardly believe it, we were so shocked and stunned by the news," says McAllister with an emotion that is part of the glory which invests the last remnant of the Grand Army of the Republic.

Nearly 35 miles a day the men in the regiment marched in their journey to Richmond and Washington. And then on May 24, 1865, was the grand review past President Andrew Johnson - past General Ulysses S. Grant - past Secretary of War Edwin Stanton - past scores of other cabinet members, senators, and other distinguished statesmen and personages of the capital. Past the reviewing stand they marched with their field equipment swinging on their persons accoutrements such as rifles, frying pans, mess kits, tin cups, haversacks, knapsacks, canteens. And the mules were there, pulling carriages and limbers. It was a tremendous sight, a remarkable experience for John McAllister. 
He was finally mustered out in Ohio, July 25, 1865.

John McAllister immediately returned to his profession, that of teaching. He remained in Ohio until March, 1866, at which time he moved westward to Cedar Rapids where relatives lived. He was married in 1871, and in 1921 he and his wife celebrated their golden wedding anniversary.

For a while after emigrating to Iowa he taught school in Benton and Linn counties. For 34 years he farmed in this county, and in 1904 retired and moved to Cedar Rapids where he has made his home ever since.

In 1903 he was elected state representative from Linn county. He served in the thirtieth, thirty-second, and thirtysecond extra general assemblies. In the thirty-second general assembly he was chairman of the military committee; he was the author of the soldier roster bill and the bill to prevent desecration of Memorial day...

\section{Man of Peace}

But in spite of his splendid record as a soldier, John McAllister is a man of peace. And looking backward over the years, conjuring in his memory new visions of the men he knew - Sherman, Garfield, Thomas - he sees them, too, as first of all men of peace.

" "War is hell," " he asserts with feeling, quiting a phrase popularly ascribed to his former commanding general. "And you can't make anything else out of it." John McAllister's friends say that he is the kind of a patriot who loves his country so intensely that he is jealous of her every movement and policy, for he cannot bear to see America wrong in her dealings with other nations and in relation to any of her citizens. 
Copyright of Annals of Iowa is the property of State of Iowa, by \& through the State Historical Society of Iowa and its content may not be copied or emailed to multiple sites or posted to a listserv without the copyright holder's express written permission. However, users may print, download, or email articles for individual use. 